\title{
Correction: Examining the complexity of functioning in persons with spinal cord injury attending first rehabilitation in Switzerland using structural equation modelling
}

\author{
Jsabel Hodel $(\mathbb{D} \cdot$ Cristina Ehrmann - Gerold Stucki - Jerome E. Bickenbach - Birgit Prodinger - and the SwiSCI \\ Study Group
}

Published online: 8 April 2020

(c) The Author(s) 2020. This article is published with open access

\author{
Correction to: Spinal Cord \\ https://doi.org/10.1038/s41393-020-0428-4 \\ published online 13 February 2020
}

Following publication of this article, the authors noticed an error due to incorrect naming of two groups: 'paraplegia' and 'tetraplegia'. This affects Tables 1 and 2, and the Results section. The correction is as following: In Table 1 'Paraplegia (C1-C8)/tetraplegia (T1-S5)' has now been corrected to 'Tetraplegia (C1-C8)/paraplegia (T1-S5)'. In the first paragraph of the Results section 'Participants were mainly male $(69.49 \%)$ with incomplete $(83.59 \%$ after missing data imputation) tetraplegia $(60.77 \%$ after missing data imputation)', has now been changed to 'Participants were mainly male $(69.49 \%)$ with incomplete $(83.59 \%$ after missing data imputation) paraplegia $(60.77 \%$ after missing data imputation)'. Finally, in Table 2, 'Paraplegia' and
'Tetraplegia' have been swapped to align with the correct, corresponding values. This has been corrected in both the PDF and HTML versions of the article, and does not change the interpretation of the data.

Open Access This article is licensed under a Creative Commons Attribution 4.0 International License, which permits use, sharing, adaptation, distribution and reproduction in any medium or format, as long as you give appropriate credit to the original author(s) and the source, provide a link to the Creative Commons license, and indicate if changes were made. The images or other third party material in this article are included in the article's Creative Commons license, unless indicated otherwise in a credit line to the material. If material is not included in the article's Creative Commons license and your intended use is not permitted by statutory regulation or exceeds the permitted use, you will need to obtain permission directly from the copyright holder. To view a copy of this license, visit http://creativecommons. org/licenses/by/4.0/. 